\title{
TGFBR1*6A is a potential modifier of migration and invasion in colorectal cancer cells
}

\author{
RUI ZHOU ${ }^{1}$, YING HUANG $^{2},{\text { BORAN } \mathrm{CHENG}^{2}, \mathrm{YULEI} \mathrm{WANG}^{2} \text { and BIN XIONG }}^{2,3}$ \\ Departments of ${ }^{1}$ Thyroid and Breast Surgery and ${ }^{2}$ Gastrointestinal Surgery, \\ Zhongnan Hospital of Wuhan University, Wuhan, Hubei 430071; ${ }^{3}$ Hubei Key Laboratory of \\ Tumor Biological Behaviors and Hubei Cancer Clinical Study Center, Wuhan, Hubei 430071, P.R. China
}

Received February 2, 2017; Accepted October 26, 2017

DOI: $10.3892 / \mathrm{ol} .2018 .7725$

\begin{abstract}
Type 1 transforming growth factor $\beta$ receptor (TGFBR1)*6A, a common hypomorphic variant of TGFBR1, may act as a susceptibility allele in colorectal cancer. However, the contribution of TGFBR $1 * 6$ A to colorectal cancer development is largely unknown. To test the hypothesis that TGFBR $1 * 6$ A promotes colorectal cancer invasion and metastasis via Smad-independent transforming growth factor- $\beta$ (TGF- $\beta$ ) signaling, the effect of TGFBR $1 * 6 \mathrm{~A}$ on the invasion of colorectal cancer cells was assessed. pCMV5-TGFBR $1 * 6$ A-HA plasmids were transfected into SW48 and DLD-1 cells by Lipofectamine-mediated DNA transfection. The effect of TGF- $\beta 1$ on the proliferation of SW48 and DLD-1 cells transfected with TGFBR1*6A was determined by MTT assay. The effects of the TGF- $\beta 1$ on the invasion of the transfected SW48 and DLD-1 cells were determined using Matrigel-coated plates. Transforming migrating chambers were used to determine the effects of TGF- $\beta 1$ on the migration of the transfected SW48 and DLD-1 cells. Western blot analysis was used to determine the expression of phosphorylated (p-) extracellular-signal-regulated kinase (ERK), p-P38 and p-SMAD family member 2 in SW48 cells. Using transfected TGFBR1*6A SW48 and DLD-1 cell lines our group demonstrated that, in comparison with TGFBR1*9A, TGFBR1*6A is capable of switching TGF- $\beta 1$ growth-inhibitory signals into growth-stimulatory signals which significantly increased the invasion of SW48 and DLD-1 cells. Functional
\end{abstract}

Correspondence to: Dr Bin Xiong, Department of Gastrointestinal Surgery, Zhongnan Hospital of Wuhan University, 169 Donghu Road, Wuhan, Hubei 430071, P.R. China

E-mail: binxiong88@yahoo.com

Abbreviations: $\quad$ TGF- $\beta 1, \quad$ transforming growth factor- $\beta 1$; TGFBR1, type 1 transforming growth factor $\beta$ receptor; ERK1/2, extracellular-signal-regulated kinases $1 / 2$

Key words: transforming growth factor- $\beta 1$, type 1 transforming growth factor $\beta$ receptor $* 6 \mathrm{~A}, \mathrm{p} 38$, extracellular-signal-regulated kinases $1 / 2$, colon cancer assays indicated that TGFBR1*6A weakened Smad-signaling but increased ERK and p38 signaling, which are crucial mediators of cell migration and invasion. From this, it was possible to conclude that TGFBR $1 * 6$ A enhanced SW48 cell migration and invasion through the mitogen-activated protein kinase pathway and that it may contribute to colorectal cancer progression in a TGF- $\beta 1 /$ Smad signaling-independent manner. This suggests that TGFBR1*6A may possess oncogenic properties and that it may affect the migration and invasion of colorectal cancer cells.

\section{Introduction}

The transforming growth factor- $\beta$ (TGF- $\beta$ ) pathway appears to serve a dual function in tumor development and progression. It suppresses early tumorigenesis, but also facilitates malignant transformation and invasion (1). Therefore, the function of TGF- $\beta$ in tumorigenesis is controversial (2).

There is growing evidence to suggest that constitutive and somatically acquired alterations in TGF- $\beta$ signaling are associated with an increased risk of colorectal cancer $(3,4)$. Colorectal cancer cells evade the antiproliferative effects of TGF- $\beta$ by acquiring mutations in components of this signaling pathway. Common mutations of TGF- $\beta$ pathway components, including ligands, receptors, Smads and Smad-interacting transcription factors, increases the risk of developing colorectal cancer (5-7). Cross-talk between TGF- $\beta$, Smads and other cell signaling pathways is also activated by the TGF- $\beta$ receptors, through either phosphorylation or direct interaction (8). For example, type 1 transforming growth factor $\beta$ receptor (TGFBR1) may also participate in the regulation of other non-Smad signaling pathways, including phosphoinositide 3-kinase (PI3K)/protein kinase $\mathrm{B}(\mathrm{AKT}), \mathrm{p} 38$ mitogen-activated protein kinase (MAPK) and nuclear factor- $\kappa \mathrm{B}(9)$.

TGFBR $1 * 6$ A, a common allele located at exon 1 of the TGFBR1 gene, has been reported to act as a low-penetrance tumor-susceptibility allele in human colorectal cancer cell lines. It is also less effective at transducing TGF- $\beta$ signaling compared with the TGFBR1*9A wild type (10). Functional studies have demonstrated that the TGFBR $1 * 6 \mathrm{~A}$ allele is associated with an increased risk of various different malignancies, including breast cancer and osteosarcoma (11). A meta-analysis conducted by Wang et al (12) has also indicated 
that the TGFBR $1 * 6 \mathrm{~A}$ allele increases the risk of colorectal cancer. Zhang et al (13) also concluded that TGFBR1*6A may be low-penetrance, but has a statistically significant increased risk of colorectal cancer. Furthermore, TGFBR $1 * 6 \mathrm{~A}$ has been demonstrated to increase the migration and invasion of MCF-7 breast cancer cells in response to TGF- $\beta 1$ (14). The results suggest that the variant TGFBR1*6A may serve an oncogenic function in cancer development, switching the TGF- $\beta 1$ growth inhibitory signals into growth stimulatory signals (15).

Certain studies have confirmed the presence of an association between TGFBR $1 * 6 \mathrm{~A}$ and colorectal cancer, but others have failed to establish any such association (16-18). Therefore, the molecular mechanism underlying the contribution of TGFBR $1 * 6$ A to colorectal cancer development remains under investigation and the function of this variant in colorectal cancer remains controversial (19). A combined analysis of six studies assessing TGFBR $1 * 6 \mathrm{~A}$ in colon cancer cases and controls indicated that TGFBR $1 * 6 \mathrm{~A}$ carriers were at an increased risk of developing colorectal cancer (20), but a large case control study did not confirm this association (21). Based on this controversy and the uncertain association between TGFBR1*6A and non-Smad pathways in colorectal cancer, the present study was conducted as a means to assess the effect of TGFBR $1 * 6 \mathrm{~A}$ polymorphism on colorectal cancer cells. The present study also evaluated the association between TGFBR1*6A and the non-Smad pathways in terms of tumor cell migration and invasion.

\section{Materials and methods}

Cell culture and transfection. The human colorectal cancer SW48 and DLD-1 cell lines were purchased from the American Type Culture Collection (ATCC; Manassas, VA, USA) and were cultured according to ATCC recommendations. The SW48 and DLD-1 cells were cultured in RPMI-1640 medium (Gibco; Thermo Fisher Scientific, Inc., Waltham, MA, USA) supplemented with $10 \%(\mathrm{v} / \mathrm{v})$ heat-inactivated fetal bovine serum (FBS; Gibco; Thermo Fisher Scientific, Inc.), $2 \mathrm{mM}$ glutamax (Gibco; Thermo Fisher Scientific, Inc.), $100 \mathrm{U} / \mathrm{ml}$ penicillin, $100 \mu \mathrm{g} / \mathrm{ml}$ streptomycin and $250 \mathrm{ng} / \mathrm{ml}$ amphoterycin (all Gibco; Thermo Fisher Scientific, Inc.) at $37^{\circ} \mathrm{C}$ in a humidified atmosphere including $5 \% \mathrm{CO}_{2}$. Cells were transfected with $0.5 \mu \mathrm{g} / \mathrm{ml}$ pCMV5-TGFBR1*6A-HA (supplied by Professor Boris Pasche) (22), or with an empty vector alone. Transfections were performed using Lipofectamine (Gibco; Thermo Fisher Scientific, Inc.), according to the manufacturer's protocols. Stably transfected cells were selected in the presence of $600 \mathrm{~g} / \mathrm{ml}$ Geneticin reagent (G418) (Sigma-Aldrich; Merck KGaA). For maintenance and culturing of transfectant clones, $400 \mathrm{~g} / \mathrm{ml} \mathrm{G} 418$ was added to the medium. Single-cell clones were subsequently maintained in $400 \mathrm{~g} / \mathrm{ml} \mathrm{G} 418$ and clones positive for TGFBR $1 * 6$ A expression were identified by screening via reverse transcription-polymerase chain reaction (RT-PCR).

DNA extraction and polymerase chain reaction (PCR). DNA was extracted from the colorectal cancer cells using proteinase $\mathrm{K}$ digestion (Sigma-Aldrich; Merck KGaA, Darmstadt, Germany) at $55^{\circ} \mathrm{C}$ overnight, followed by phenol/chloroform extraction and ethanol precipitation.
Subsequently, $0.5 \mathrm{ml}$ phenol/chloroform was added, samples were centrifuged at $14,000 \mathrm{x}$ g for $15 \mathrm{~min}$ at room temperature, followed by further centrifugation at $12,000 \mathrm{x} \mathrm{g}$ for $10 \mathrm{~min}$ at room temperature. The supernatant was then to a fresh cuvette, followed by the addition of $0.5 \mathrm{ml}$ chloroform, and was centrifuged at $14,000 \mathrm{x} \mathrm{g}$ for $5 \mathrm{~min}$ at room temperature, followed by further centrifugation at $12,000 \mathrm{xg}$ for $10 \mathrm{~min}$ at room temperature. Subsequently, the supernatant was transferred to a fresh cuvette, prior to the addition of $50 \mathrm{ml} 3 \mathrm{M} \mathrm{NaOAc}(\mathrm{pH}=6.0)$ and $0.5 \mathrm{ml} 100 \%$ ethanol. The cuvette was inverted several times, centrifuged at $12,000 \times \mathrm{g}$ for $10 \mathrm{~min}$ at room temperature. The pellet was then washed once with $70 \%$ ethanol and was left to air dry. The optical density (OD) 260/OD 280 of the DNA used for PCR amplification was $\sim 1.80$. The TGFBR 1 exon 1 coding sequence was as previously described, and PCR amplification was also performed as previously described (23). PCR was performed using Advantage-GC Genomic Polymerase Mix (Invitrogen; Thermo Fisher Scientific, Inc.) in a total volume of $25 \mathrm{ml}$ containing $50 \mathrm{ng}$ DNA and $1.25 \mathrm{U}$ Platinum Taq DNA polymerase (Invitrogen; Thermo Fisher Scientific, Inc.). Following initial denaturation for $10 \mathrm{~min}$ at $95^{\circ} \mathrm{C}, 35$ cycles of PCR amplification were performed as follows: $95^{\circ} \mathrm{C}$ for $1 \mathrm{~min}, 68^{\circ} \mathrm{C}$ for $1 \mathrm{~min}$, and $72^{\circ} \mathrm{C}$ for $1 \mathrm{~min}$ followed by a 5 -min final extension at $72^{\circ} \mathrm{C}$. For single-strand conformation polymorphism analysis, PCR products $(5 \mu \mathrm{l})$ were diluted with $15 \mu$ l loading buffer (10 mM EDTA, 98\% deionized formamide and $5 \mathrm{mg} / \mathrm{ml}$ Blue Dextran 2000). Denaturation through heating was performed at $98^{\circ} \mathrm{C}$ for $10 \mathrm{~min}$, and then quenched on ice for $2 \mathrm{~min}$. Then, $20 \mu \mathrm{l}$ of this solution was added to each lane of an $8 \%$ neutral polyacrylamide gel. Electrophoresis was performed at $300 \mathrm{~V}$ in $1 \mathrm{X}$ TAE (Tris-acetate-EDTA) buffer (Sigma-Aldrich; Merck $\mathrm{KGaA}$ ) at a temperature of $10^{\circ} \mathrm{C}$. The DNA was purified using the QIAquick PCR purification kit (Qiagen $\mathrm{GmbH}$, Hilden, Germany), according to the manufacturer's protocol. Finally, purified DNA fragments were directly sequenced by the same forward or reverse primers utilized in the original PCR amplification (Thermo Fisher Scientific, Inc.), performed as previously described (22).

Cell proliferation assay. Cells $\left(1 \times 10^{4}\right)$ were seeded onto 96 -well plates. The cell growth mediated by TGF- $\beta 1$ was determined using an MTT assay. To assess the growth inhibitory effects of TGF- $\beta 1$, sw48, control vector-modified sw48 and TGFBR1*6A-modified sw48 (sw48/TGFBR1*6A) cells were seeded, at a density of 10,000 cells/well, onto 96 well plates in RPMI-1640 medium (Gibco; Thermo Fisher Scientific, Inc.) supplemented with $10 \%$ (v/v) heat-inactivated fetal bovine serum (FBS; Gibco; Thermo Fisher Scientific, Inc.), and were incubated for $48 \mathrm{~h}$ prior to incubation for $48 \mathrm{~h}$ in serum-free Dulbecco's modified Eagle's medium (Gibco; Thermo Fisher Scientific, Inc.) in the absence or presence of TGF- $\beta 1(5 \mathrm{ng} / \mathrm{ml})$. The assay was initiated by adding MTT solution at a final concentration of $100 \mu \mathrm{g} \mathrm{MTT/well.} \mathrm{Wells} \mathrm{were} \mathrm{then} \mathrm{aspirated,}$ $100 \mu \mathrm{l}$ dimethyl sulfoxide (Sigma-Aldrich; Merck KGaA) was added to each well to dissolve the purple formazan, and the plate was agitated for $15 \mathrm{~min}$. Cells were subsequently subjected to MTT assays at discrete time periods of 24, 48 and $72 \mathrm{~h}$. Plates were read at $460 \mathrm{~nm}$ in a spectrophotometer. 
In vitro invasion/migration assays. BioCoat Matrigel invasion chambers [12-well cell culture inserts containing an $8.0 \mu \mathrm{m}$ polyethylene terephthalate (PET) membrane with a uniform layer of Matrigel matrix; BD Biosciences, Franklin Lakes, NJ, USA] were used to assess cell invasion. Cell migration was assessed in BioCoat control cell culture chambers (12-well cell culture inserts containing an $8.0 \mu \mathrm{m}$ PET membrane without a Matrigel layer). The membranes (1.0 ml/chamber) were rehydrated with warm serum-free Dulbecco's modified Eagle's medium (Sigma-Aldrich; Merck KGaA) for 2 h. In brief, cells that were pre-incubated for $48 \mathrm{~h}$ at room temperature in minimum essential medium (MEM; Sigma-Aldrich; Merck KGaA), in the presence or absence of $5 \mathrm{ng} / \mathrm{ml}$ TGF- $\beta 1$, were seeded into the upper wells at a density of $0.5 \times 10^{5}$ cells/500 $\mu \mathrm{l}$ MEM. The lower chambers were filled with MEM (Sigma-Aldrich; Merck KGaA) containing 10\% FBS, which acted as a chemoattractant. The chambers were incubated for $48 \mathrm{~h}$ at $37^{\circ} \mathrm{C}$ in a $5 \% \mathrm{CO}_{2}$ atmosphere. Cells from the upper surface of the membranes were removed by scrubbing with a cotton swab. Those on the lower surface of the membranes were fixed for $5 \mathrm{~min}$ at room temperature with $100 \%$ methanol and stained with Wright-Giemsa [0.4\% (w/v) in methanol, pH 6.8); Sigma-Aldrich; Merck KGaA)] for 2 min at room temperature. The number of cells that penetrated into each filter was counted in five random optical microscopic fields, under x 20 magnification, by a technician unaware of the experimental settings. The percentage of invading cells was expressed as the ratio of the mean cell number from the invasion chamber to the mean cell number from the control chamber, according to the manufacturer's protocols. Each assay was performed on duplicate filters and the experiments were repeated twice.

Western blot analysis. A total of $48 \mathrm{~h}$ after transfection, the supernatant from the cells was transferred to a $10-\mathrm{cm}$ petri dish, prior to being used for western blot analysis. Cells were washed with cold phosphate-buffered saline and were lysed in $70 \mu$ lysis buffer [50 mM Tris- $\mathrm{Cl}$ (pH 8.1), $10 \mathrm{mM}$ EDTA, $1 \%$ SDS, $1 \%$ protein inhibitor; Beyotime Institute of Biotechnology, Haimen, China] for $10 \mathrm{~min}$ at $4^{\circ} \mathrm{C}$. Cell lysates were centrifuged at $5,000 \mathrm{x} \mathrm{g}$ at $4^{\circ} \mathrm{C}$ for $10 \mathrm{~min}$ to pellet the cell lysates. The concentration of cellular protein was determined using a BCA Protein Assay kit (Beyotime Institute of Biotechnology). Total protein $(60 \mu \mathrm{g})$ was mixed with a $5 \mathrm{X}$ loading buffer, heated at $100^{\circ} \mathrm{C}$ for $5 \mathrm{~min}$, and separated on $10 \%$ sodium dodecyl sulfate-polyacrylamide gels. Following electrophoresis, the proteins were transferred onto a Millipore Immobilon-P transfer membrane (EMD Millipore, Billerica, MA, USA) using a Semi-Dry system (Bio-Rad Laboratories, Inc., Hercules, CA, USA) with Tris buffer (0.025 M Tris- $\mathrm{HCl}$, $0.192 \mathrm{M}$ glycine, and $20 \% \mathrm{MeOH})$. The membrane was blocked for $1 \mathrm{~h}$ at room temperature with $5 \%$ non-fat milk in TBS-Tween 20. Subsequently, the membranes were incubated at $4^{\circ} \mathrm{C}$ overnight with the following antibodies: Mouse monoclonal antibodies against $\beta$-actin (dilution, 1:1,000; cat. no. sc-70319; Santa Cruz Biotechnology, Inc., Dallas, TX, USA) and SMAD family member $2(\operatorname{Smad} 2$; dilution, 1:500; cat. no. sc133098; Santa Cruz Biotechnology, Inc.), and rabbit polyclonal antibodies against phosphorylated (p)-Smad2 (Ser465/467; dilution, 1:800; cat. no. 8828; Cell Signaling Technology, Inc., Danvers, MA, USA), p38 MAPK (dilution,
Table I. Analysis of TGFBR1 mutation in colorectal cancer cell lines.

\begin{tabular}{lll}
$\begin{array}{l}\text { Cell } \\
\text { line }\end{array}$ & \multicolumn{1}{c}{ GCG repeats } & $\begin{array}{c}\text { TGFBR1 } \\
\text { mutant }\end{array}$ \\
\hline DLD-1 & CTGGCG GCG GCG GCG GCG GCG & $* 6 \mathrm{~A} / 9 \mathrm{~A}$ \\
& CTGCTCCCGGGGCCACGGGT & $* 9 \mathrm{~A} / 9 \mathrm{~A}$ \\
SW48 & $\begin{array}{l}\text { CTGGCG GCG GCG GCG GCG } \\
\text { GCG GCG GCG GCG CTGCTCCCGG }\end{array}$ & \\
\cline { 2 - 2 } & GGGCGACGGGTGAGCGGCGGCGC & \\
\hline
\end{tabular}

TGFR1, type 1 transforming growth factor $\beta$ receptor.

1:800; cat. no. 8690; Cell Signaling Technology, Inc.), p-p38 (Thr180/Tyr182) MAPK (dilution, 1:1,000; cat. no. 9211; Cell Signaling Technology, Inc.), extracellular-signal-regulated kinases 1/2 (ERK1/2; dilution, 1:800; cat. no. 9102; Cell Signaling Technology, Inc.) and p-Erk1/2 (Thr202/Tyr204; dilution, 1:800; cat. no. 9106; Cell Signaling Technology, Inc.). Following washing in TBS-Tween20 3 times, the membranes were then incubated with a horseradish peroxidase-conjugated anti-mouse immunoglobulin $\mathrm{G}$ (IgG) (dilution, 1:1,000; cat. no. 14709) and anti-rabbit IgG against (p)-Smad2 (dilution, 1:1,000; cat. no. 14708; both Cell Signaling Technology, Inc.) for $1 \mathrm{~h}$ at room temperature. The membranes were subsequently incubated with BeyoECL Plus reagents (Beyotime Institute of Biotechnology), according to the manufacturer's protocols. Images were captured using a motored molecular imaging system (Molecular Imaging Vilber Fusion X7; Vilber Lourmat, Marne-la-Vallée, France).

Statistical analysis. Results were presented as the mean \pm standard deviation and were analyzed using GraphPad Prism 5 software (GraphPad Software, Inc., La Jolla, CA, USA). Differences between groups were assessed using two-way analysis of variance, followed by Tukey's post hoc test. $\mathrm{P}<0.05$ was considered to indicate a statistically significant difference. All experiments were repeated at least 3 times.

\section{Results}

Analysis of TGFBR1 mutations in colorectal cancer cell lines. To investigate potential TGFBR1 alterations in colorectal cancer cell lines, PCR and sequencing was performed on SW48 and DLD-1 cell lines. SW48 cells were confirmed to carry a TGFBR $1 * 9 \mathrm{~A} / * 9 \mathrm{~A}$ genotype, and DLD-1 cells carried a *6A/*9A genotype (Table I). SW48 and DLD-1 cell lines were then selected for further research.

TGFBRI*6A increases colorectal cancer cell proliferation. To investigate whether the TGFBR $1 * 6$ A allele increased colorectal cancer cell proliferation, the TGF- $\beta 1$-mediated proliferation of SW48 and DLD-1 cells was assessed following transfection with TGFBR1*6A plasmids or an empty vector. As presented in Fig. 1A-C, when compared with other controls, the proliferation of SW48 cells was inhibited when exposed to TGF- $\beta 1$ $(5 \mathrm{ng} / \mathrm{ml})$ for 24,48 and $72 \mathrm{~h}(\mathrm{P}<0.05)$. However, when SW48 
A
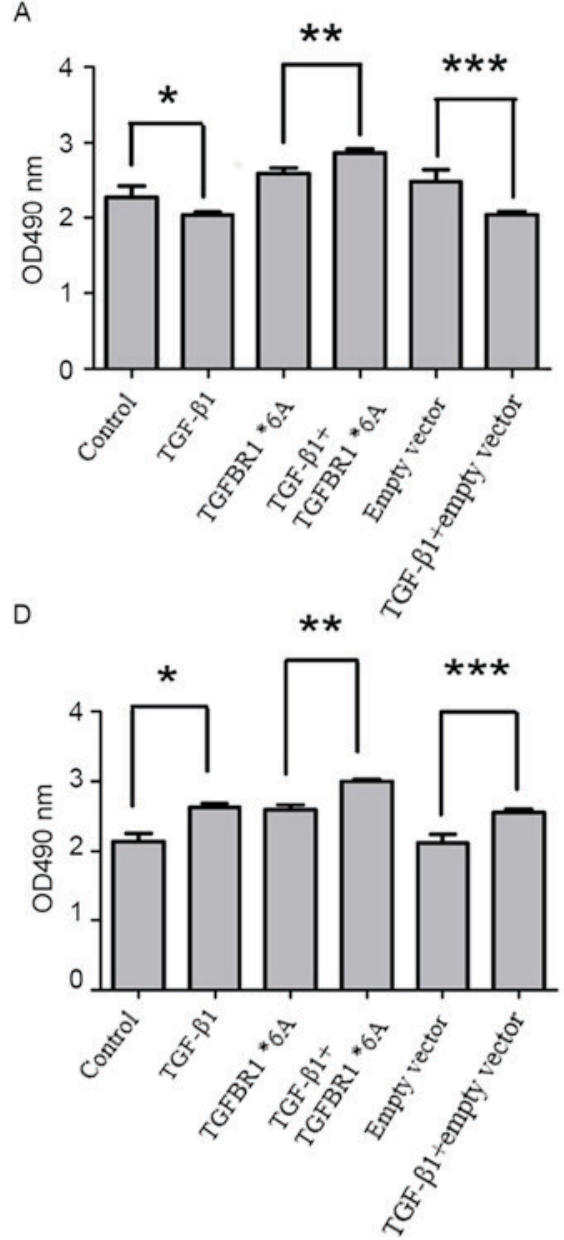

B
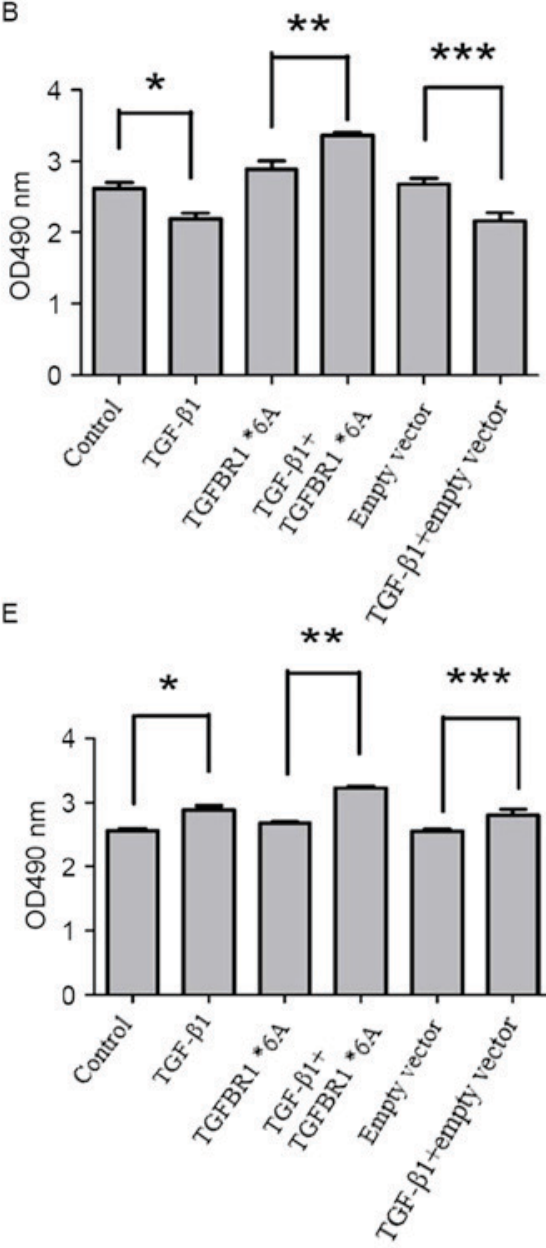
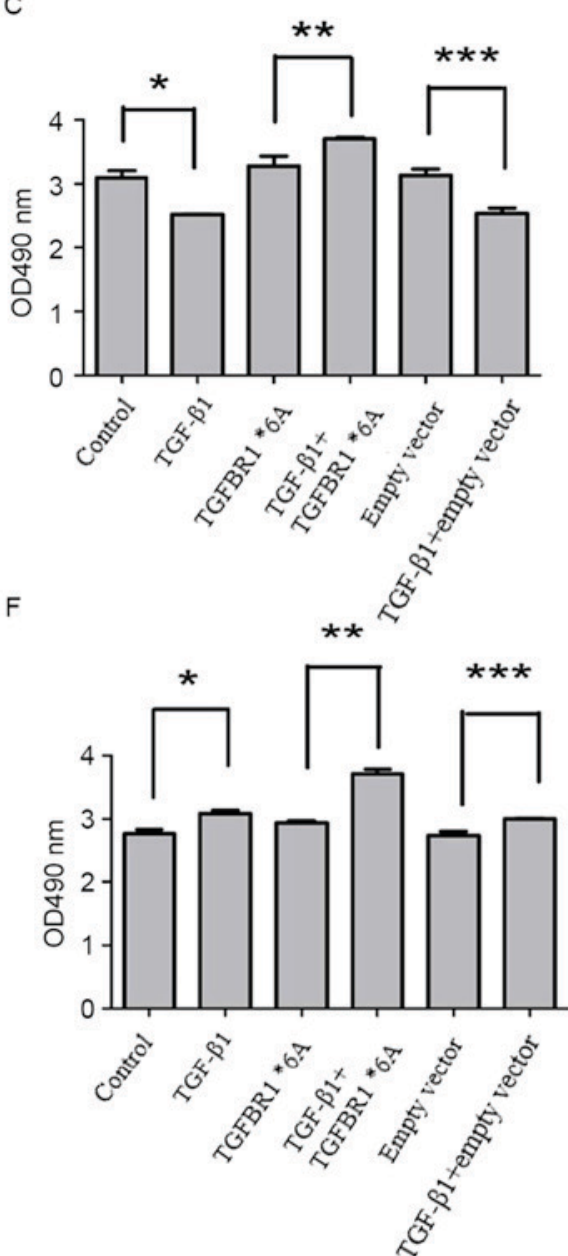

Figure 1. TGFBR1*6A increased colorectal cancer cell proliferation when exposed to TGF- $\beta 1$ ( $5 \mathrm{ng} / \mathrm{ml})$, as assessed via MTT assays. The proliferation of SW48 cells was assessed at (A) 24, (B) 48 and (C) $72 \mathrm{~h}$, and the proliferation of DLD-1 cells was assessed at (D) 24 , (E) 48 and (F) $72 \mathrm{~h}$. Each experiment was performed at least 4 times in triplicate. ${ }^{*} \mathrm{P}<0.05,{ }^{* *} \mathrm{P}<0.01$ and ${ }^{* * * *} \mathrm{P}<0.001$, with comparisons indicated by lines. TGFBR $1^{*} 6 \mathrm{~A}$, type 1 transforming growth factor $\beta$ receptor; TGF- $\beta 1$, transforming growth factor- $\beta 1$.

cells were transfected with TGFBR $1 * 6$ A plasmids, the proliferation of these cells increased following exposure to TGF- $\beta 1$ (5 ng/ml) for 24,48 and $72 \mathrm{~h}$, compared with those not treated with TGF- $\beta 1$ (Fig. 1A-C; $\mathrm{P}<0.05$ ). These data suggested that the overexpression of TGFBR1*6A may promote cell growth and tumorigenicity in colorectal cancer cells. Fig. 1D-F demonstrate that DLD-1 cell proliferation increased following exposure to TGF- $\beta 1(5 \mathrm{ng} / \mathrm{ml})$ for 24,48 and $72 \mathrm{~h}$ compared with controls $(\mathrm{P}<0.05)$. Furthermore, the proliferation of DLD-1 cells transfected with TGFBR1*6A plasmids treated with TGF- $\beta 1$ ( $5 \mathrm{ng} / \mathrm{ml})$ was increased compared with control cells that were not treated with TGF- $\beta 1$ (Fig. 1D-F; P<0.05). These phenomena suggested that TGFBR $1 * 6 \mathrm{~A}$ may switch TGF- $\beta 1$-mediated inhibition of proliferation into stimulation of proliferation in colorectal cancer cells. Each experiment was performed at least 4 times in triplicate.

TGFBR1*6A increases invasion in colorectal cancer cells. To test the hypothesis that TGFBR $1 * 6 \mathrm{~A}$ is involved in colorectal cancer development and progression, its ability to modify migration and invasion was assessed in SW48 and DLD-1 cells transfected with TGFBR $1 * 6$ A plasmids or empty vectors. In the presence of TGF- $\beta 1(5 \mathrm{ng} / \mathrm{ml})$, overexpression of
TGFBR1*6A in DLD-1 cells significantly increased invasion compared with the controls (Fig. 2). Similarly, overexpression of TGFBR1*6A in SW48 cells resulted in increased invasion compared with the controls (Fig. 2). These data indicated that TGFBR $1 * 6$ A increased invasion in colorectal cancer cells.

TGFBRI*6A promotes the development and progression of colorectal cancer via p38 and ERK MAPK signaling. To investigate the potential mechanisms underlying the TGFBR $1 * 6 \mathrm{~A}$-induced switch from TGF- $\beta 1$-mediated inhibition of proliferation to stimulation of proliferation in colorectal cancer cells, a signaling test was performed using western blotting. Increased expression of p-p38 and p-ERK1/2 was detected within 15-30 min of stimulation with exogenous TGF- $\beta 1(5 \mathrm{ng} / \mathrm{ml})$ in SW48 cells that were transfected with TGFBR $1 * 6$ A plasmids, compared with those transfected with the empty vector (Fig. 3). Following treatment with TGF- $\beta 1$ $(5 \mathrm{ng} / \mathrm{ml})$, the empty vector and wild type SW48 (TGFBRI*9A) cells exhibited activated $\mathrm{p}-\mathrm{Smad} 2$ signaling, compared with those transfected with TGFBR1*6A, in which the protein expression of $\mathrm{p}-\mathrm{Smad} 2$ was decreased, but the protein expression of p-p38 was markedly increased and that of p-ERK was slightly increased (Fig. 3). Therefore, when treated with 


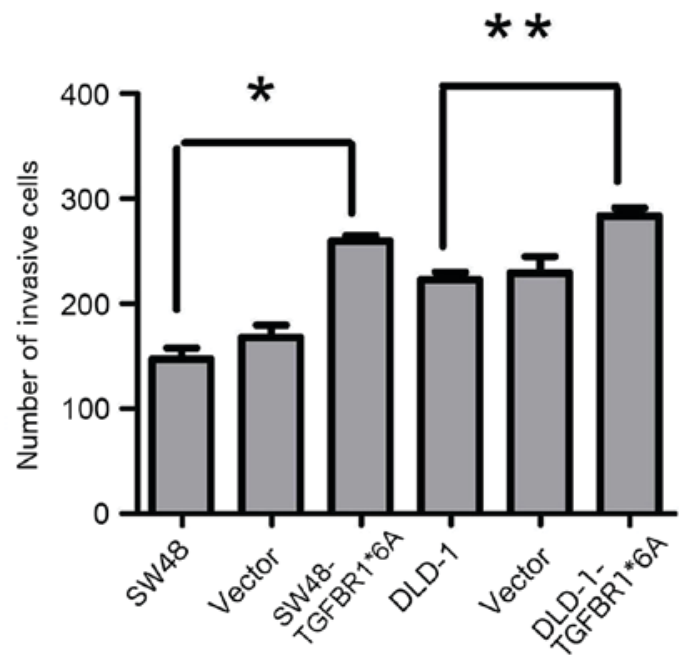

Figure 2. TGFBR $1 * 6 \mathrm{~A}$ enhanced invasion and metastasis in colorectal cancer cells when exposed to transforming growth factor- $\beta 1(5 \mathrm{ng} / \mathrm{ml})$, as assessed using Matrigel-coated invasion chambers. ${ }^{*} \mathrm{P}<0.05$ and ${ }^{* * *} \mathrm{P}<0.01$, with comparisons indicated by lines. TGFBR $1 * 6 \mathrm{~A}$, type 1 transforming growth factor $\beta$ receptor.

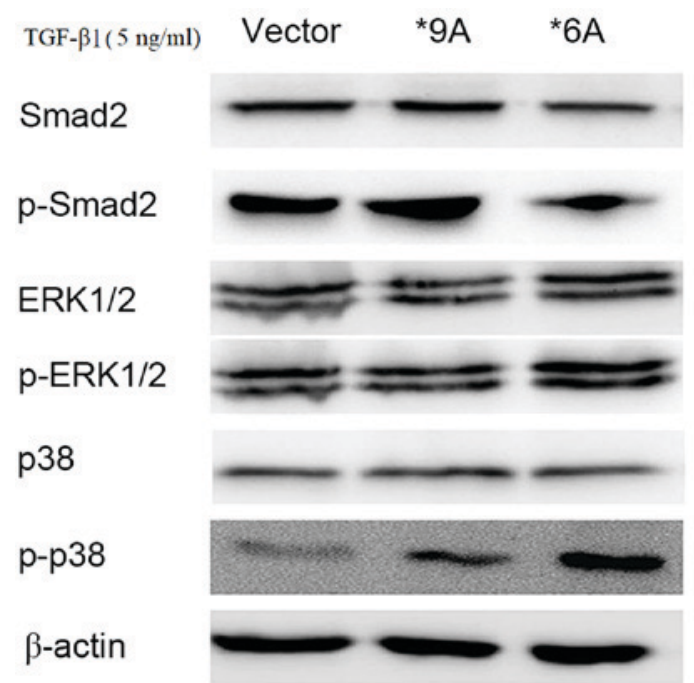

Figure 3. To investigate the potential mechanisms underlying the TGFBR $1 * 6$ A-induced switch from TGF- $\beta 1$-mediated growth inhibition to growth stimulation in SW48 colorectal cancer cells, western blotting was performed. Western blotting demonstrating that increased expression of p-p38 and p-ERK1/2 were detected within 15-30 min of stimulation with exogenous TGF- $\beta 1(5 \mathrm{ng} / \mathrm{ml})$ in SW48 cells transfected with a *6A plasmid. When treated with TGF- $\beta 1(5 \mathrm{ng} / \mathrm{ml})$, the wild type SW48 (TGFBR $1 * 9 A)$ and controls cells activated $\mathrm{p}$-Smad 2 signaling, but only induced little activation of p-p38 and p-ERK signaling. However, under the same conditions in SW48-*6A cells, TGF- $\beta 1$ activated both p-p38 and p-ERK signaling, while the expression of $\mathrm{p}$-Smad 2 was decreased. TGFBR $1 * 6 \mathrm{~A}$, type 1 transforming growth factor $\beta$ receptor; TGF- $\beta 1$, transforming growth factor- $\beta 1$; ERK, extracellular-signal-regulated kinase; MAPK, mitogen-activated protein kinase; p-, phosphorylated; Smad2, SMAD family member 2.

TGF- $\beta(5 \mathrm{ng} / \mathrm{ml})$, the wild type SW48 (TGFBRI*9A) and empty vector control cells activated $\mathrm{p}$-Smad 2 signaling, but only induced little activation of p-p38 and p-ERK signaling (Fig. 3). These results indicated that the TGFBR $1 * 6$ A allele may cause increased activity of the p38 and ERK1/2 MAPK signaling pathways rather than the TGF- $\beta 1 /$ Smad signaling pathway, compared with wild type and control cells. This may facilitate the switch in TGF- $\beta 1$-mediated signaling to result in proliferation and invasion in colorectal cancer cells.

\section{Discussion}

In normal epithelial cells, TGF- $\beta$ predominantly inhibits growth and serves as a tumor suppressor. However, during the development and progression of malignancies, TGF- $\beta$ is transformed into a tumor promoter. Loss of TGF- $\beta$-mediated inhibition of growth appears to be a common, important event that occurs in colorectal cancer (24). Multiple colorectal cancer cell lines escape from the tumor-suppressive effect of TGF- $\beta$, becoming resistant to TGF- $\beta$-induced growth inhibition.

There is a growing body of evidence to demonstrated that TGF- $\beta$ signaling alterations mediated by mutations or polymorphisms of TGF- $\beta$ receptors contribute to the development and progression of colon cancer. TGFBR $1 * 6 \mathrm{~A}$ is a common polymorphic variant of the TGF- $\beta$ receptor I gene, and an association between TGFBR $1 * 6 \mathrm{~A}$ and human colorectal cancer has previously been reported (23). Studies conducted by Pasche et al (23) revealed that there is a significantly higher TGFBR $1 * 6 \mathrm{~A}$ allelic frequency in patients with colorectal cancer than in healthy controls. Furthermore, TGFBR $1 * 6 \mathrm{~A}$ was somatically acquired during colorectal cancer tumorigenesis and liver metastasis (15). In the present study, SW48 and DLD1 cells were transfected with pCMV5-TGFBR1*6A-HA plasmids or with the empty vector. Our group observed that TGFBR $1 * 6$ A-mediated growth inhibition was weaker than TGFBR $1 * 9 A-m e d i a t e d$ growth inhibition when exposed to $5 \mathrm{ng} / \mathrm{ml}$ TGF- $\beta 1$. Transfection of TGFBR $1 * 6 \mathrm{~A}$ into the colorectal cancer cells resulted in a significant increase in cellular invasion. However, the difference between the TGFBR $1 * 6 \mathrm{~A}$ cells and TGFBR $1 * 9 \mathrm{~A}$ cells was independent of TGF- $\beta 1 /$ Smad signaling, suggesting that TGFBR $1 * 6 A$ may switch TGF- $\beta 1$ growth inhibitory signals into growth stimulatory signals via Smad-independent pathways. A previous study has demonstrated that the biological effects of TGFBR $1 * 6 A$ are mediated by the signal sequence rather than by the mature receptor,TGFBR1 (14). Following cleavage, the signal sequence remains in the cytoplasm, and may modulate specific gene expression or other cellular functions. Therefore, the observed effects are likely due to secondary signaling events triggered by the TGFBR $1 * 6$ A signal sequence. TGFBR $1 * 6$ A may drive the proliferation of colorectal cancer cells in conjunction with other oncogenic pathways, including the Ras/MAPK, c-Jun $\mathrm{N}$-terminal kinase (JNK) or PI3K/AKT pathways.

The MAPK pathways transduce a large variety of external signals and lead to a wide range of cellular responses, including growth, differentiation, inflammation and apoptosis. Three distinct MAPK pathways have been described in mammalian cells, including the ERK pathway, the JNK pathway, and the p38 MAPK pathway (25). The present study demonstrated that transfection of SW48 cells with the TGFBR $1 * 6$ A plasmid resulted in the upregulation of p-p38 and p-ERK protein expression. These results have led us to hypothesize that TGFBR $1 * 6$ A may facilitate SW48 cell metastasis and invasion by increasing the activation of the p38 and ERK1/2 MAKP pathways.

In summary, the TGFBR $1 * 6 \mathrm{~A}$ allele increases SW48 colorectal cancer cell invasion and results in the activation 
of the p38 MAPK and ERK1/2 MAPK pathways. In the present study, these effects were observed in the absence of exogenously added TGF- $\beta 1$. Furthermore, the TGFBR $1 * 6 \mathrm{~A}$ phenotype may be a mediator that switches TGF- $\beta 1$ growth inhibitory signals into growth stimulatory signals. As a result of the dual role of TGF- $\beta 1$ in tumorigenesis, a comprehensive understanding of TGFBR $1 * 6 \mathrm{~A}$ biology is required in order to design successful therapeutics. It is important to discover novel drugs that mimic the interactions between TGF- $\beta$ and its receptors and mechanistically inhibit transduction of TGF- $\beta$ signaling and, in turn, eliminate the tumor-promoting activities of TGF- $\beta$.

\section{References}

1. David CJ, Huang YH, Chen M, Su J, Zou Y, Bardeesy N, Iacobuzio-Donahue CA and Massagué J: TGF- $\beta$ tumor suppression through a lethal EMT. Cell 164: 1015-1030, 2016.

2. Principe DR, Doll JA, Bauer J, Jung B, Munshi HG, Bartholin L, Pasche B, Lee C and Grippo PJ: TGF- $\beta$ : Duality of function between tumor prevention and carcinogenesis. J Natl Cancer Inst 106: djt369, 2014.

3. Mehrvarz Sarshekeh A, Advani S, Overman MJ, Manyam G, Kee BK, Fogelman DR, Dasari A, Raghav K, Vilar E, Manuel S, et al: Association of SMAD4 mutation with patient demographics, tumor characteristics and clinical outcomes in colorectal cancer. PLoS One 12: e0173345, 2017.

4. Ramamoorthi G and Sivalingam N: Molecular mechanism of TGF- $\beta$ signaling pathway in colon carcinogenesis and status of curcumin as chemopreventive strategy. Tumour Biol 35: 7295-7305, 2014.

5. PLOS ONE Staff: Correction: Association of SMAD4 mutation with patient demographics, tumor characteristics and clinical outcomes in colorectal cancer. PLoS One 12 : e0178275, 2017.

6. Fleming NI, Jorissen RN, Mouradov D, Christie M, Sakthianandeswaren A, Palmieri M, Day F, Li S, Tsui C, Lipton L, et al: SMAD2, SMAD3 and SMAD4 mutations in colorectal cancer. Cancer Res 73: 725-735, 2013.

7. Sarshekeh AM, Overman MJ, Kee BK, Fogelman DR, Dasari A and Singh Raghav KP: Demographic, tumor characteristics and outcomes associated with SMAD4 mutation in colorectal cancer. J Clin Oncol 34: 565, 2016.

8. Sun XF, Sun XH, Cheng SF, Wang JJ, Feng YN, Zhao Y, Yin S, Hou ZM, Shen W and Zhang XF: Interaction of the transforming growth factor- $\beta$ and Notch signaling pathways in the regulation of granulosa cell proliferation. Reprod Fertil Dev 28: 1873-1881, 2015.

9. LiuWT,Huang KY,LuMC,Huang HL,ChenCY,Cheng YL, YuHC, Liu SQ, Lai NS and Huang HB: TGF- $\beta$ upregulates the translation of USP15 via the PI3K/AKT pathway to promote p53 stability. Oncogene 36: 2715-2723, 2017.

10. Jung B, Staudacher JJ and Beauchamp D: Transforming growth factor $\beta$ super family signaling in development of colorectal cancer. Gastroenterology 152: 36-52, 2016
11. Hu YS, Pan Y, Li WH, Zhang Y, Li J and Ma BA: Association between TGFBR1*6A and osteosarcoma: A Chinese case-control study. BMC Cancer 10: 169, 2010.

12. Wang Y, Qi X, Wang F, Jiang J and Guo QN: Association between TGFBR 1 polymorphisms and cancer risk: A meta-analysis of 35 case-control studies. PLoS One 7: e42899, 2012.

13. Zhang X, Wu L, Sheng Y, Zhou W, Huang Z, Qu J, Gao G, Cai D and Zhang M: The association of polymorphisms on TGFBR1 and colorectal cancer risk: A meta-analysis. Mol Biol Rep 39: 2567-2574, 2012.

14. Rosman DS, Phukan S, Huang CC and Pasche B: TGFBR1*6A enhances the migration and invasion of MCF-7 breast cancer cells through rhoa activation. Cancer Res 68: 1319-1328, 2008.

15. Pasche B, Pennison MJ, Jimenez $\mathrm{H}$ and Wang M: TGFBR1 and cancer susceptibility. Trans Am Clin Climatol Assoc 125: 300-312, 2014

16. Castillejo A, Mata-Balaguer T, Montenegro P, Ochoa E, Lázaro R, Martínez-Cantó A, Castillejo MI, Guarinos C, Barberá VM, Guillén-Ponce C, et al: The TGFBR $1 * 6 \mathrm{~A}$, allele is not associated with susceptibility to colorectal cancer in a Spanish population: A case-control study. BMC Cancer 9: 193, 2009.

17. Ross JP, Lockett LJ, Tabor B, Saunders IW, Young GP, Macrae F, Blanco I, Capella G, Brown GS, Lockett TJ and Hannan GN: Little evidence for association between the TGFBR1*6A variant and colorectal cancer: A family-based association study on non-syndromic family members from Australia and Spain. BMC Cancer 14: 475, 2014.

18. McGuire JL, Mcphail M and Rajendran A: The association of $\operatorname{tgf} \beta$ signalling pathway gene polymorphisms with colorectal cancer risk: A meta-analysis. Gastroenterology 146: S868-S8683, 2014.

19. Ibrahim T, Yazbeck C, Maalouly G, Haddad F, Sabbagh C and Chahine G: TGFBR1*6A polymorphism in sporadic and familial colorectal Carcinoma: A case-control study and systematic literature review. J Gastrointestinal Cancer 45: 441-447, 2014.

20. Pasche B, Kaklamani V, Hou N, Young T, Rademaker A Peterlongo P, Ellis N, Offit K, Caldes T, Reiss M and Zheng T: TGFBR 1*6A and cancer: A meta-analysis of 12 case-control studies. J Clin Oncol 22: 756-758, 2004.

21. Ross JP, Lockett LJ, Tabor B, Saunders IW, Young GP, Macrae F, Blanco I, Capella G, Brown GS, Lockett TJ and Hannan GN: Little evidence for association between the TGFBR $1 * 6 \mathrm{~A}$ variant and colorectal cancer: A family-based association study on non-syndromic family members from Australia and Spain. BMC Cancer 14: 475, 2014.

22. Pasche B, Luo Y, Rao PH, Nimer SD, Dmitrovsky E, Caron P, Luzzatto L, Offit K, Cordon-Cardo C and Renault B: Type I transforming growth factor beta receptor maps to $9 \mathrm{q} 22$ and exhibits a polymorphism and a rare variant within a polyalanine tract. Cancer Res 58: 2727-2732, 1998

23. Pasche B, Knobloch TJ, Bian Y, Liu J, Phukan S, Rosman D, Kaklamani V, Baddi L, Siddiqui FS, Frankel W, et al: Somatic acquisition and signaling of TGFBR $1 * 6$ A in cancer. JAMA 294: 1634-1646, 2005.

24. Wu WK, Wang XJ, Cheng AS, Luo MX, Ng SS, To KF, Chan FK, Cho $\mathrm{CH}$, Sung JJ and Yu J: Dysregulation and crosstalk of cellular signaling pathways in colon carcinogenesis. Crit Rev Oncol Hematol 86: 251-277, 2013.

25. Taves S, Berta T, Liu DL, Gan S, Chen G, Kim YH, Van de Ven T, Laufer S and Ji RR: Spinal inhibition of p38 MAP kinase reduces inflammatory and neuropathic pain in male but not female mice: Sex-dependent microglial signaling in the spinal cord. Brain Behav Immun 55: 70-81, 2016. 